\title{
EFFECT USE OF PULSED DEFICIT DRIP IRRIGATION FOR TOMATO CROP IN GREENHOUSE POWERED BY SOLAR ENERGY
}

\section{Ahmed I. Abd-Elhakim ${ }^{1 \& *}$, Mohammed I. Elmeadawy ${ }^{2}$, Islam M. El-Sybaee ${ }^{2}$ and Mohsen I. Egela ${ }^{3}$}

${ }^{1}$ Assist. Prof., Irrigation and Drainage Eng. Dept., Ag. Eng. Res. Inst., ARC, Dokki, Giza, Egypt.

${ }^{2}$ Assist. Prof., Power and Energy Eng. Dept., Ag. Eng. Res. Inst., ARC, Dokki, Giza, Egypt.

${ }^{3}$ Assoc. Prof., Biological Eng. Dept., Ag. Eng. Res. Inst., ARC, Dokki, Giza, Egypt.

* elhakem19777@gmail.com

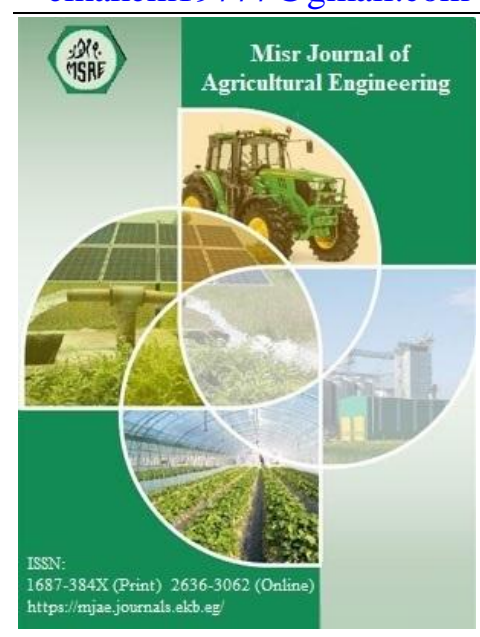

(C) Misr J. Ag. Eng. (MJAE)
Keywords:

Pulsed-deficit drip

irrigation, solar energy,

tomato.

\section{ABSTRACT}

The presented study aims to investigate the effect of using two effective irrigation techniques; the pulse-deficit drip irrigation and the deficit irrigation powered by solar energy in a greenhouse. This work studied impact of these factors a tomato soilless productivity, water productivity and of these techniques solar energy productivity. The experimental study was carried out at Tractors and Farm Machinery Research and Test Station, Alexandria Governorate. The results showed that, the pulsed-full drip irrigation at_100\% of ETc (FP100) gave the highest yield of 35.8 ton/fed., but the continuous- deficit drip irrigation at $50 \%$ of ETc (DC50) gave the lowest yield of 20.4 ton/feddan. The highest water productivity (WP) was $37.1 \mathrm{~kg} / \mathrm{m}^{3}$ when using the treatment of (DP50), on the other hand the Continuous-Full drip irrigation at 100\% of ETC (FC100) (control treatment) represents the lowest WP of $27.9 \mathrm{~kg} / \mathrm{m}^{3}$. Application of pulse-deficit irrigation (DP50) saved $50 \%$ of the water irrigation requirements and decreased the total tomato yield per feddan by $34 \%$, but the water productivity increased by $33 \%$ compared with continuous-full irrigation (FC100) as control. Treatment of pulse-deficit irrigation (DP50) saved 50\% of solar energy consumption and increase energy productivity $(908 \mathrm{~kg} / \mathrm{kWh})$ by $33 \%$ compared to continuous-full irrigation (FC100) as control. The results showed that pulse-deficit drip irrigation technique, decrease tomato yield but increase WP in all treatments. This study recommend apply, pulse-deficit irrigation (DP75) technique results in reducing tomato yield by $3 \%$ and increasing water and energy productivity by 29.3 and $29.4 \%$ respectively.

\section{INTRODUCTION}

$\mathrm{T}$ The country lies within the semi-arid regions with limited water resources and this need to find effective irrigation techniques to rationalize and save irrigation water aim to sustainable agricultural irrigation. Tomato is one of the vegetable crops of worldwide demand because of its various purposes including nutritional, economic and medicinal values (Savić et al., 2008). It is also an important constituent of daily diet worldwide. Tomato 
considered as vegetables being sensitive to water deficit. Availability of water can considerably influence crop yield and quality (Salokhe et al., 2005).

Deficit irrigation (DI) considered worldwide as a way of maximizing water productivity (WP). It eliminating irrigations that have little impact on yield, while save water and improve fruit quality (English, 1990; English and Raja, 1996; Kirda et al., 1999; Karam, et al., 2007). Moreover, Kirnak et al. (2002) pointed out that yield loss that may result from deficit irrigation is offset by the benefits of reduced water use. Deficit irrigation (DI) can cause some problems as water stress and limit crop transpiration, but many studies have found that moderate water stress can improve water productivity (WP) (Tognetti et al., 2004; Chen et al., 2013; Qiu et al., 2015; Dijkstra et al., 2016; Khapte, et al., 2019). Also, it is found that deficit irrigation with partial root zone drying as $85 \%$ of the water requirement of the plant was the best method for hydroponic cultivation of tomato (Hooshmand, et al., 2019). A lot of benefits of deficit irrigation in terms of improved quality and water productivity while sustaining fruit yield could be achieved with regulated DI at $0.8 x E T c$ and DI at $0.6 x E T c$ during vegetative stage followed by flowering (Nangare, et al., 2016). Silveira, et al., (2020) found that deficit irrigation management at $50 \%$ ETc is a better water saving strategy. Al-Ghobari \& Dewidar, 2018; Yu, et al., (2020) studies demonstrated that deficit irrigation is a promising practice, the regional environment and proper deficit irrigation methods should be carefully considered.

Pulse drip irrigation is an experimental irrigation technique primarily used for maintaining a high level of soil moisture for seeds germination. Pulsed drip irrigation refer to the practice of irrigating for a short period then waiting for another short period, and repeating this on-off cycle until the entire irrigation water is applied (Eric et al., 2004). Pulse drip irrigation is used in a lot of arid and semi-arid regions, largely to reduce water losses and to improve crop yields and water productivity. Applying pulse drip irrigation technique lead to increase in water movement in horizontal direction more than vertical direction thus increasing in water soil volume (Li, et al., 2004; Bakeer, et al., 2009; Skaggs et al.,2010; Abdel tawab, 2015). Ismail, et al., (2014) and Abd-elhakim (2019) reported that the advantage of pulse flow, for reducing the deep percolation of water under the crop root zone, while obtaining a wide horizontal spread of wetting. This enables using a highly discharge emitter with the same amount of water.

Solar irrigation has become a life saver for farmers struggling to water crops amidst rising electricity costs in rural areas around the world. Where, it's in Mediterranean areas, as its climate is characterized by a high number of sunlight hours. Therefore, an irrigation photovoltaic energy system is increasingly gaining interest. Solar powered irrigation technology can be utilized by independent farmers in small-scale remote rural farms in Sub-Saharan Africa (Wazed, et al., 2017). Also, micro-irrigation system integrated with low cost solar based pumping system was designed to suit small holders whereas, Adoption of such system would help in conservation of energy and mitigate the climate change (Kumar, et al., 2015). Solarpowered agricultural irrigation is an attractive application of renewable energy due to the rise in Oil prices and the upscaling in commercialisation of PV technology. However, to be practical it must be both technically and economically feasible. especially as it reaches more competitive levels with other energy sources in terms of cost, may serve to sustain the lives of millions of under privileged people in developing countries. Furthermore, solar energy devices can benefit the environment and economy of developing countries (Kelley et al., 2010; Devabhaktuni et 
al., 2013). Based on the literature the most effective $P V$ system is presented for the irrigation of a small scare remote rural farm with respect to the cost, pumping capacity and system efficiency (Wazed et al., 2018).

The study aim effect of using two irrigation techniques; the pulse-deficit drip irrigation powered by solar energy in greenhouse and study their impact on the Tomato soilless productivity, water productivity and solar energy productivity.

\section{MATERIAL \& METHODS}

\section{Field experiment description and treatments}

The field experiments were carried out in buckets for tomato culture 'Super Marmande variety' in a polyethylene greenhouse (dimensions: length of $12 \mathrm{~m}$, width of $4 \mathrm{~m}$, and height in the range of 2-3m). It has the planting area of $32 \mathrm{~m}^{2}$. The greenhouse situated at Tractors and Farm Machinery Research and Test Station, Alexandria Governorate (Latitude $31.24 \mathrm{~N}$, and Longitude 29.98 E) during one season 2019-2020 from 20 October to the end of February. Weather data for experimental site was taken from El-Nouzha airport station, Alexandria Governorate, Egypt that include daily observations for temperature $\left({ }^{\circ} \mathrm{C}\right)$, humidity $(\%)$, wind speed $(\mathrm{mph})$, and precipitation $(\mathrm{mm})$. Weather data inside greenhouse were measured using Environment Meter apparatus (EM9300SD). It is Environment instrument, multi-function, and four in one. The experimental field was divided into six treatments. The treatment was divided into 4 replicates. Each replicate was specified as bucket (bucket scale $0.25 \mathrm{X} 0.25 \mathrm{~m}$ width X length with $0.40 \mathrm{~m}$ depth), each bucket is planted two seedlings. Growth media in bucket was shown in table (1), distance between buckets was $50 \mathrm{~cm}$, the drip irrigation system used lateral lines contained in-line GR emitters of $4 \mathrm{l} / \mathrm{hr}$ discharge, where each bucket used one emitter. The irrigation techniques are pulsed drip irrigation at cycle ratio equal 0.5 for cycle time (30minutes). The pulse-deficit and deficit drip irrigation was at 50, 75, and 100\% of tomato crop water requirements, ETc. ETo was calculated using Pan evaporation method. Pan evaporation, Ep data was get from site of Central Laboratory for agricultural Climate as an average of six years (1999-2005). Pan factor, kp was 0.85. ETo in greenhouse was equal 70\% multiple ETo in open field (Khalil, 1998). Values of crop coefficient, Kc were get from tables and reduction factor for drip irrigation, $\mathrm{kr}$ (Ismail, 2002). Hence, it was calculated ETc. Fertilizer program for tomato crop during drip irrigation follows prescribed doses in technical bulletin Zaki, et al., (2010). Drip irrigation system powered by solar photovoltaic with DC pump used to study the effect of Pulsed-Deficit drip irrigation technique on solar energy consumption rate. Components of Solar pumping system were the solar panel $(0.40 * 0.55 \mathrm{~m})$, the charging unit (10) Amp, 12 volts was delivers a signal to charges battery, the battery sealed lead acid battery 12V - 9 Amp, and D.C. pump 12 Volts 15 Watt, flow 4.5 LPM and press 6.8 bar. Experimental site description was shown in Fig. (1). The statistical analysis were carried out based on completely randomized design (CRD). The obtained data analyzed by (Minitab) software package (version16). The mean values of the six treatments were compared using L.S.D. test at a significance level of 0.05 as follows:

1. Continuous-Full drip irrigation technique at $100 \%$ ETc (FC100).

2. Continuous- Deficit drip irrigation technique at $75 \%$ ETc (DC75).

3. Continuous- Deficit drip irrigation technique at 50\% ETc (DC50).

4. Pulsed-Full drip irrigation technique at $100 \%$ ETc (FP100). 
5. Pulsed- Deficit drip irrigation technique at $75 \%$ ETc (DP75).

6. Pulsed- Deficit drip irrigation technique at 50\% ETc (DP50).

\section{Measurements and calculations}

1. Soil analysis for growth media: texture and chemical analysis for the used soil was carried out in Soil Salinity Laboratory- agricultural research center as shown in Tables (1 through 3). Table (1): The growth media texture and physical properties.

\begin{tabular}{lllllll}
\hline $\begin{array}{l}\text { Soil } \\
\text { Depth }\end{array}$ & $\begin{array}{l}\text { Clay } \\
(\%)\end{array}$ & $\begin{array}{l}\text { Silt } \\
(\%)\end{array}$ & $\begin{array}{l}\text { Sand } \\
(\%)\end{array}$ & $\begin{array}{l}\text { Soil } \\
\text { texture }\end{array}$ & $\begin{array}{l}\text { Organic } \\
\text { matter }(\%)\end{array}$ & $\begin{array}{l}\text { Bulk density } \\
(\mathrm{g} / \mathrm{cm} 3)\end{array}$ \\
\hline $0-40 \mathrm{~cm}$ & 21.55 & 30.14 & 47.11 & Loam & 1.2 & $1.22-1.33$ \\
\hline
\end{tabular}

Table (2): Chemical analysis for Growth media in bucket.

\begin{tabular}{lccccccccc}
\hline Soil & & \multicolumn{2}{c}{ EC } & \multicolumn{4}{c}{ Cations, meq/1 } & \multicolumn{3}{c}{ Anions, meq/l } \\
\cline { 3 - 10 } Depth & PH & mmhos/ & $\mathrm{Ca}$ & $\mathrm{Mg}$ & $\mathrm{Na}$ & $\mathrm{K}$ & $\mathrm{HCO} 3-$ & $\mathrm{Cl}-$ & $\mathrm{SO} 4--$ \\
\hline $0-40$ & 6.8 & 1.6 & 6.5 & 12.5 & 25 & 0.1 & 8.1 & 28.9 & 5 \\
\hline
\end{tabular}

Table (3): Fertilizers elements for growth media in bucket.

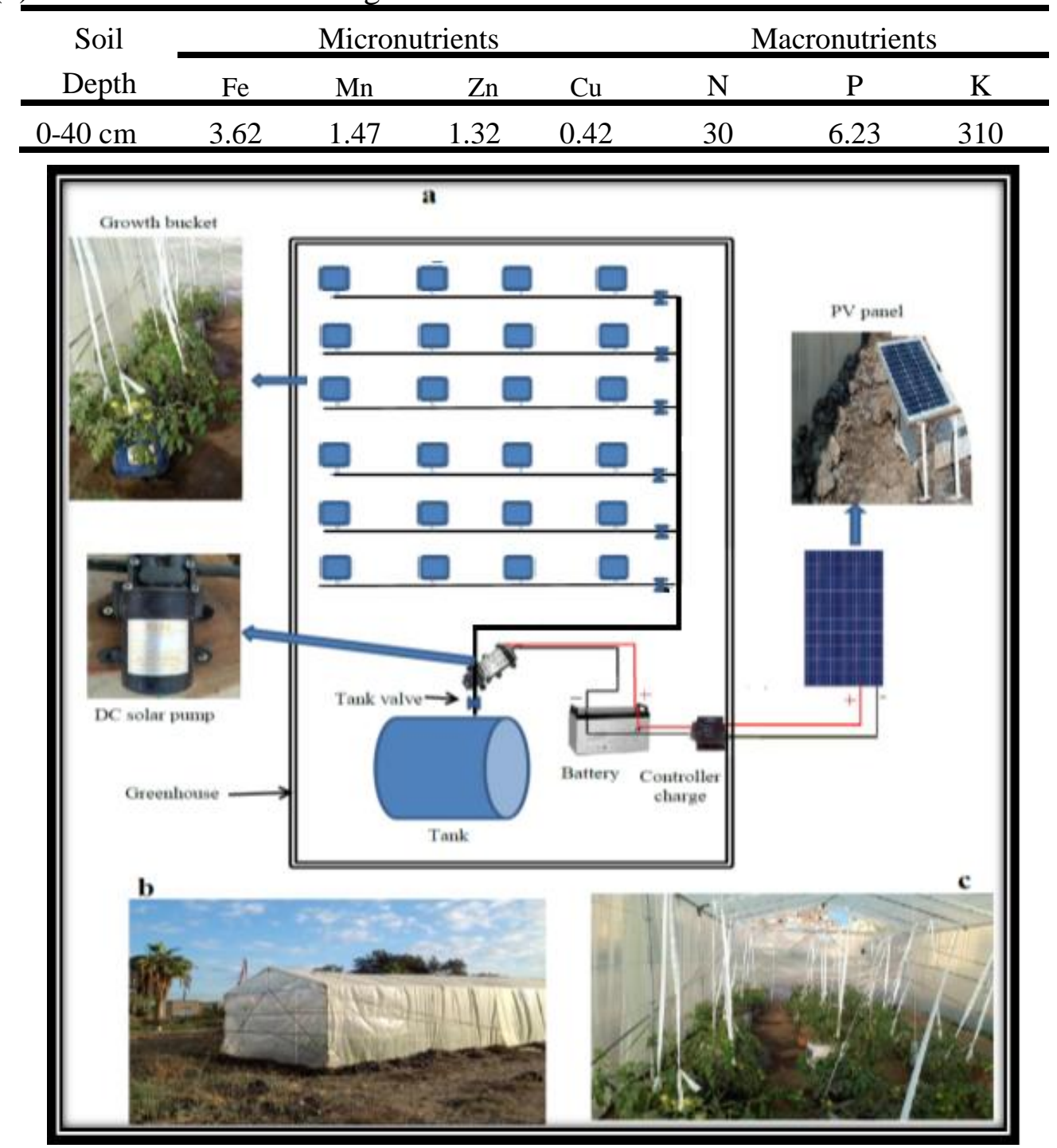

Fig. (1): Layout of pulsed deficit drip irrigation system in greenhouse powered by PV solar energy for cultivated tomato in bucket: a) Diagram of experiment components; b) Outside greenhouse; and c) Inside greenhouse. 
2. Moisture content for growth media: Soil samples were taken to determine the water content in the growth media in buckets by auger from the soil profile after 12 hours irrigation on distances of $10 \mathrm{~cm}$ from emitter and depth of $(0-15 \mathrm{~cm})$ and $(15-30 \mathrm{~cm})$ from the emitter. Soil moisture content was determined by the gravimetric methods.

3. Tomato yield and quality parameters: Harvesting tomato was started within 102 and 130 days after transplanting for one season. The tomato yield was determined for each bucket and that represented treatment. The tomatoes were hand harvested and weighted using a sensitive scale $0.01 \mathrm{gm}$ with a capacity of $2 \mathrm{~kg}$ and adjusted to tomato yield in ton/fed. Total fruit yield; $\mathrm{T}$ Yield, marketable yield; $\mathrm{M}$ Yield (the non-marketable yield included yellow fruits and fruits having blossom end rot; BER), the number of fruit per plant; FN/plant and the average weight of the fruit per plant; FW were determined.

4. Water productivity: Water productivity was calculated according to James (1988) as follows: -

$$
\mathrm{WP}=\frac{\mathrm{y}}{\mathrm{w}_{\mathrm{a}}}
$$

Where, WP is Water productivity, $\mathrm{kg} / \mathrm{m}^{3}$, $\mathrm{y}$ is Total crop yield, $\mathrm{kg} / \mathrm{fed}$, and $\mathrm{w}_{\mathrm{a}}$ is Total applied water, $\mathrm{m}^{3} / \mathrm{fed}$. Total applied water was calculated assist the relations and equations from references (Khalil, 1998 and Ismail, 2002).

5. Required PV solar energy: Required solar energy for irrigation relies on several parameters including pump head, suction head, pipes length, and volumetric flow rate. Equation (2) shows the solar energy as a function of some important parameters (Kelley et al., 2010):

$$
E_{p v s}=\frac{r \times g \times Q \times h \times t \times n}{E_{p} \times E_{p v} \times 3600}
$$

Where, Epvs is PV system energy ( $\mathrm{kWh} / \mathrm{season}), \mathrm{r}$ is water density $\left(1000 \mathrm{~kg} / \mathrm{m}^{3}\right), \mathrm{g}$ is gravitational acceleration $\left(9.81 \mathrm{~m} / \mathrm{s}^{2}\right)$, Q is volumetric flow rate $\left(\mathrm{m}^{3} / \mathrm{h}\right), \mathrm{h}$ is pumping head $(\mathrm{m}), \mathrm{t}$ is daily operating time ( $\mathrm{hr}$ ), $\mathrm{n}$ is number of days during season, Ep is DC-pump efficiency (90\%), and Epv is PV cell efficiency $(74 \%)$, respectively.

6. Solar energy productivity: The solar energy productivity for pumping irrigation water during the tomato growth season was calculated as follows:-

$$
\mathrm{SEP}=\frac{\mathrm{y}}{\mathrm{Epvs}}
$$

Where, SEP is solar energy productivity, $\mathrm{kg} / \mathrm{kWh}$, y is Total crop yield, $\mathrm{kg} / \mathrm{fed}$, and $\mathrm{E}_{\mathrm{pvs}}$ is PV consumption solar energy for pumping irrigation water during the tomato growth season (kWh/season).

\section{RESULTS \& DISCUSSIONS}

\section{Meteorology conditions}

Ambient weather data (air temperature, dew point, relative humidity and wind speed at $2 \mathrm{~m}$ height) were daily recorded during growth season from 22 October up to the end of February. Air temperature in experiment site was ranged from 10.9 to $25.3{ }^{\circ} \mathrm{C}$ with an average of $17.3{ }^{\circ} \mathrm{C}$ as shown in Fig. (2), where the optimum temperature in the greenhouse for tomato growth is ranged from 21 to $29{ }^{\circ} \mathrm{C}$ as mentioned by Zaki, et al., (2010). Therefore, the daily mean air temperature in the greenhouse was $24.8^{\circ} \mathrm{C}$ during growth season. Air temperature at dew point outside greenhouse was ranged from 3.5 to $19.8^{\circ} \mathrm{C}$ ) with an average of $11.2^{\circ} \mathrm{C}$ as shown in Fig. (2). The daily mean air temperature at dew point inside greenhouse was $13{ }^{\circ} \mathrm{C}$. Relative 
humidity in study site was ranged between (50.5 -85.6\%) with an average of $69 \%$ as shown in Fig. (3). The optimum range of relative humidity for growth tomato is ranged from 60 to $70 \%$ which conforms to (Zaki, et al., 2010). Therefore, the daily mean relative humidity inside the greenhouse was $66 \%$ during growth season.

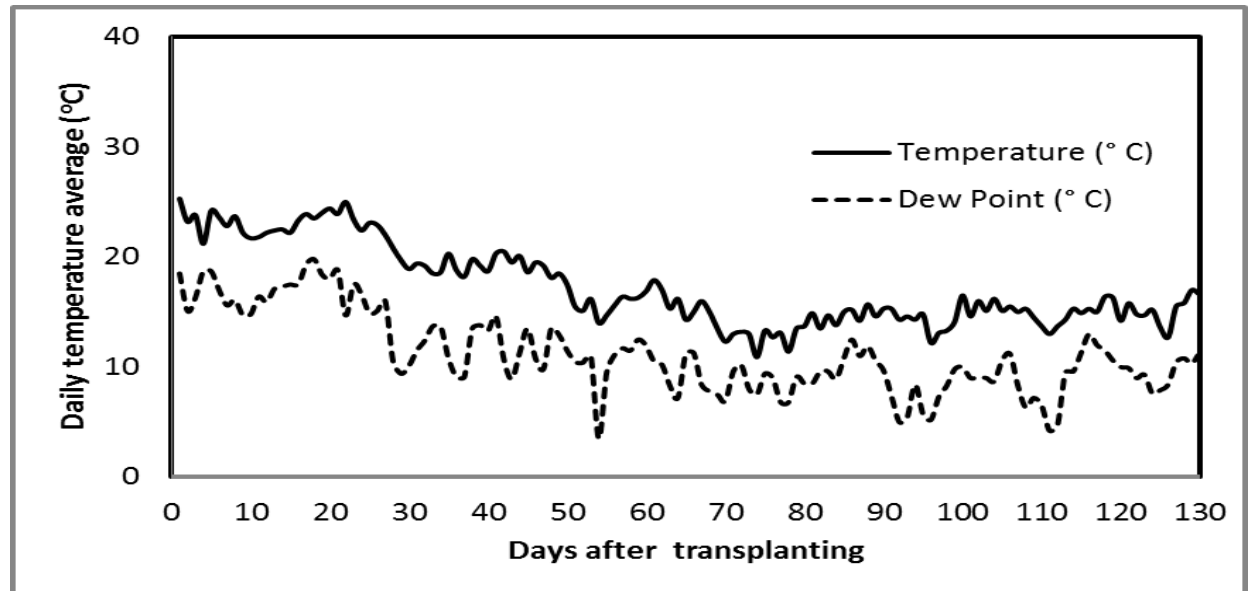

Fig.(2): Average daily temperature $\left({ }^{\circ} \mathrm{C}\right)$ for experiment site during tomato growth season from 22 October up to the end of February

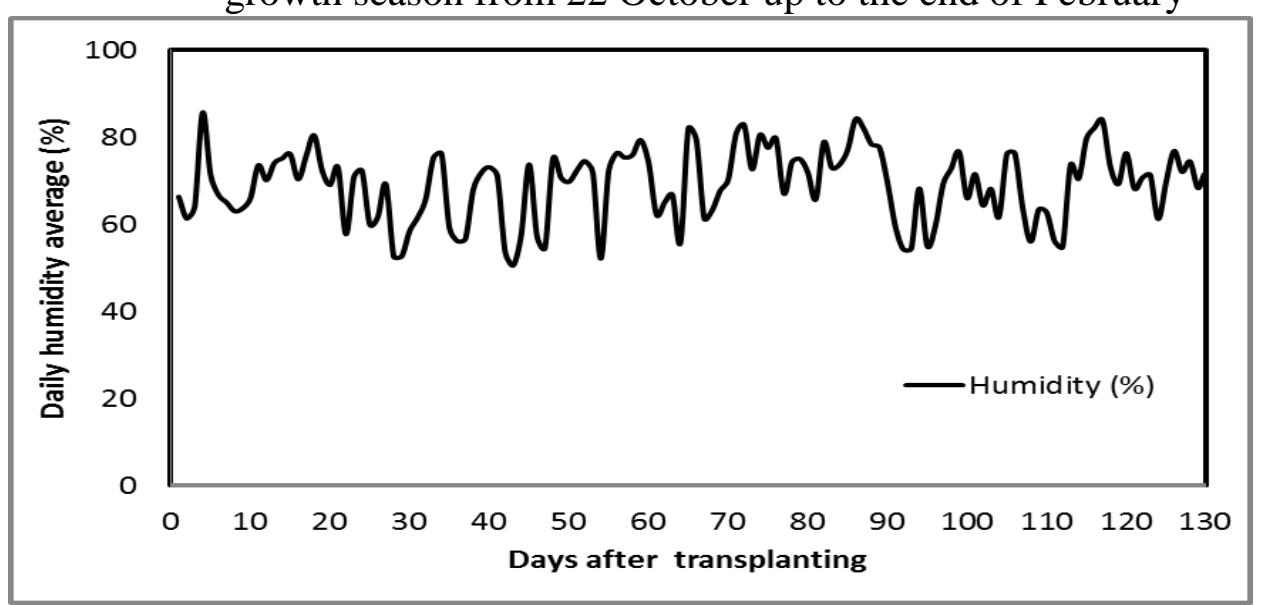

Fig. (3): Average daily air humidity (\%) for experiment site during tomato growth season from 22 October up to the end of February.

\section{Moisture content; MC}

Through measurements it was noticed that, the averaged moisture content for tomato growth media after one day irrigation in Buckets increased largely using Pulsed-Deficit drip irrigation techniques compared to deficit irrigation techniques only as shown in Fig. (4). which was reflected in reduce water losses and the increase of tomato crop yield and irrigation water productivity, in addition to increase in moisture content percent which conforms to (Ismail, et al., (2014) and Abd-elhakim, 2019).

\section{Tomatoes yield and quality parameters:}

\section{a. The number of fruits per plant; FN/plant}

The average numbers of tomato fruits per plant (FN/plant) were $(31,30,29,29,25$, and 25 fruits/plant) for FP100, FC100, DP75, DC75, DP50 and DC50 treatments respectively as shown in Fig. (5). The highest number of tomato fruits per plant were 31 fruits/plant in the treatment of FP100 despite it was exposed to water stress for using deficit irrigation techniques. It can be noted that there were no significant difference in the average number of tomato fruits per plant 
as result of applying pulse-deficit drip irrigation techniques especially at level $75 \%$ of irrigation water requirements. The statistical analysis showed that, there were significant effects at the 0.01 probability level due to irrigation treatments on number of fruits per plant as shown in table (4).

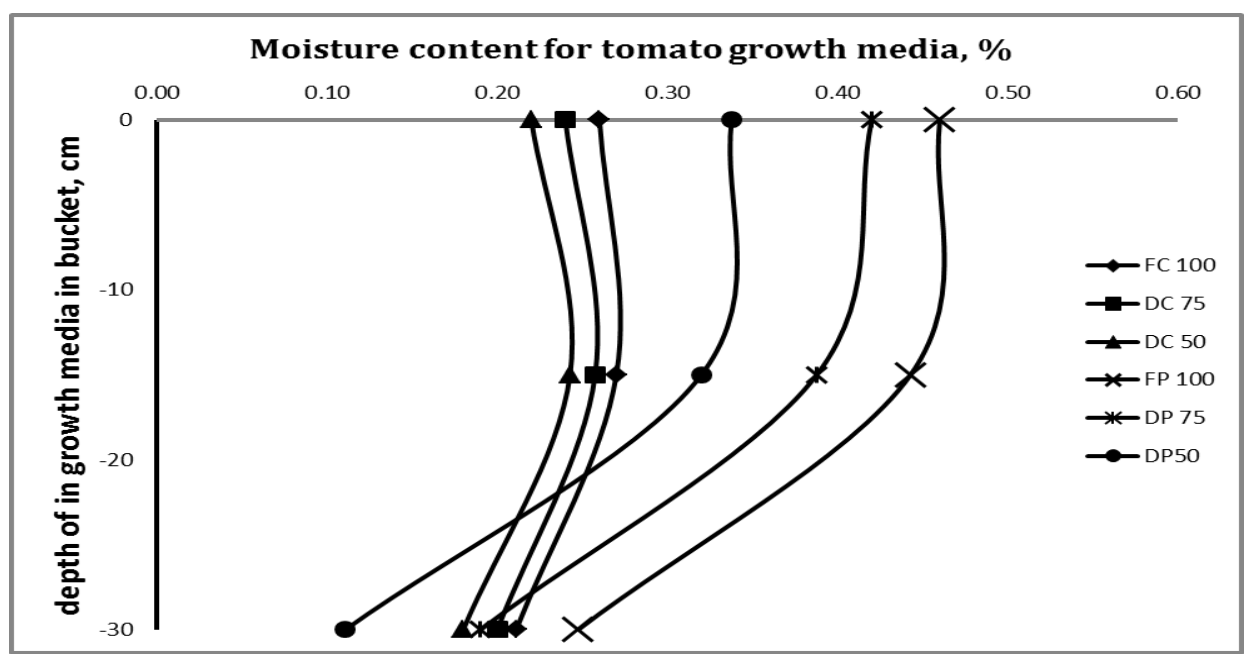

Fig. (4): The average moisture content for tomato growth media after one day of irrigation.

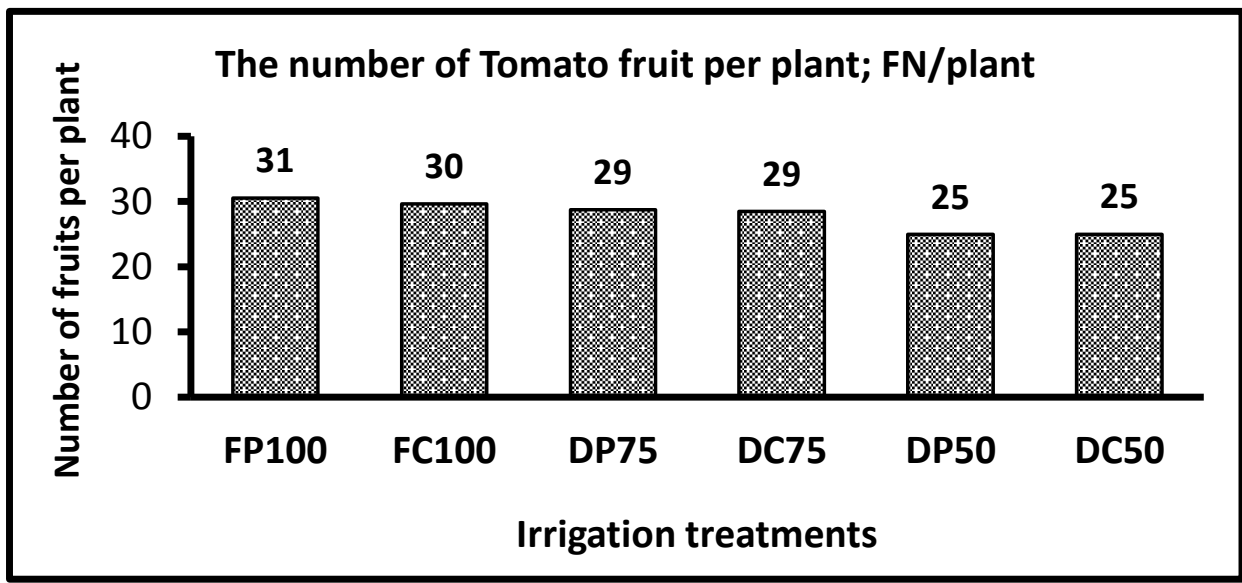

Fig. (5): The number of tomato fruits per plant under different irrigation treatments.

\section{b. The average weight of the fruit per plant; FW}

The average weight of tomato fruit per plant (FW) were $(69.7,66.9,66.9,64.4,54$, and 45.6 g/fruit per plant) for FP100, FC100, DP75, DC75, DP50 and DC50 for treatments respectively as shown in Fig. (6). Results showed that the average weight of the fruit per plant was the highest in the pulse-deficit drip irrigation more than continuous-deficit irrigation techniques. The highest weight of tomato fruit per plant were in the treatment of FP100 (69.7 g/fruit) but, the lowest weight of tomato fruit per plant were in the treatment of DC50 (45.6 g/fruit). It can be noted there were no significant difference in the average weight of tomato fruits per plant. These were results of applying pulse-deficit drip irrigation techniques at levels of $100,75 \%$ irrigation water requirements compared to continuous-deficit techniques, but there was reducing clear in at level of 50\% irrigation water requirements. The statistical analysis showed that, there were significant effects at the 0.01 probability level due to irrigation treatments on the average weight of fruit per plant as shown in table (4). 


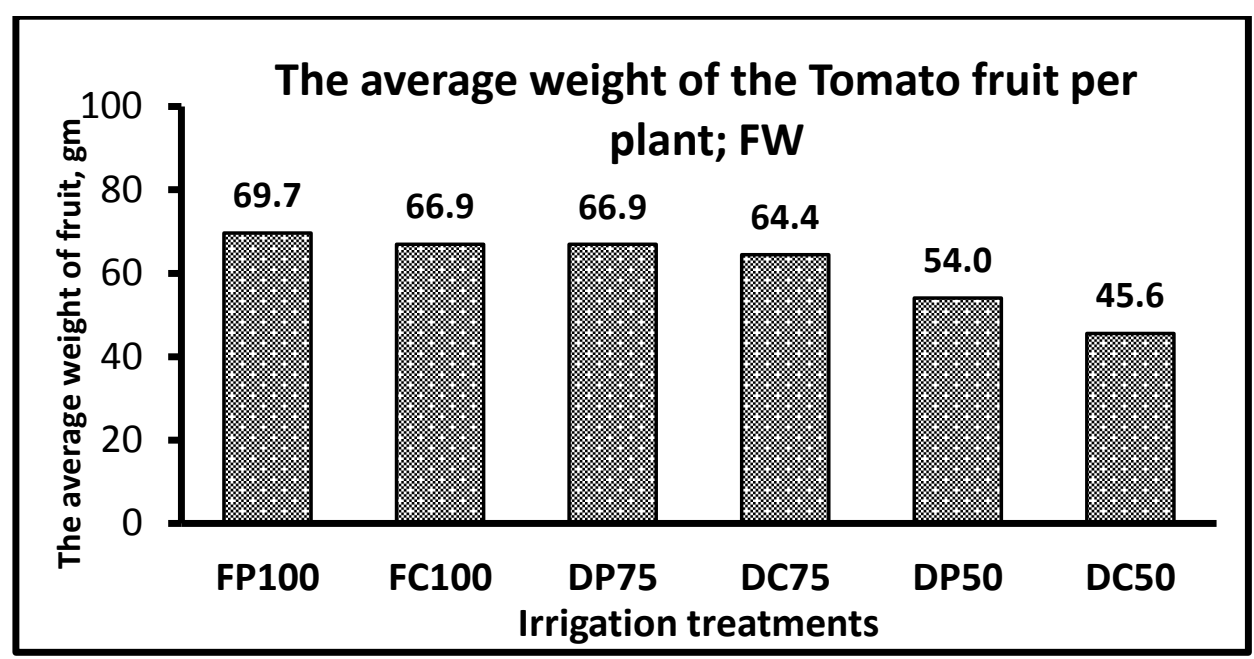

Fig. (6): The average weight of the fruit per plant; FW under different irrigation treatments.

\section{c. Tomato yield per plant}

The tomato yield per plant (FY) was $(2.1,2,1.9,1.8,1.3$, and $1.2 \mathrm{~kg} / \mathrm{plant})$ for FP100, FC100, DP75, DC75, DP50 and DC50 for treatments respective as shown in Fig. (7). Results showed that the tomato yield per plant (FY) was the highest in the pulse-deficit drip irrigation as compared with the continuous-deficit irrigation techniques. The highest yield per plant were in the treatment of FP100 (2.1 kg/plant) but, the lowest yield per plant were in the treatment of DC50 $(1.2 \mathrm{~kg} / \mathrm{plant})$. It can be noted there were significant difference in the yield per plant as result of applying pulse-deficit drip irrigation techniques led to increase the yield per plant compared to continuous-deficit techniques, but there was reducing clear in yield at using only deficit irrigation technique. The statistical analysis showed that, there were significant effects at the 0.01 probability level due to irrigation treatments on the tomato yield per plant as shown in table (4).

\section{d. Total Tomato yield; $T$ Yield,}

The total tomato yield per feddan (TYield) were (35.8, 33.3, 32.3, 30.9, 22.1 and 20.4 ton/fed) for FP100, FC100, DP75, DC75, DP50 and DC50 for treatments respective as shown in Fig. (8). Results showed that the total tomato yield per feddan (TYield) was the highest in the pulsedeficit drip irrigation more than continuous-deficit irrigation techniques by $(7,4$, and $8 \%$ ) for levels of $(100,75$, and $50 \%)$ respectively. The highest total tomato yield per feddan was in the treatment of FP100 (35.8 ton/fed) but, the lowest yield per plant were in the treatment of DC50 (20.4 ton/fed). It can be noted there were clear significant difference in the total tomato yield per feddan as result of applying pulse-deficit drip irrigation techniques led to increase the total yield compared to continuous-deficit techniques, but there was reducing clear in yield at using only deficit irrigation technique. The statistical analysis showed that, there were significant effects at the 0.01 probability level due to irrigation treatments on the total tomato yield per feddan as shown in Table (4).

\section{e. Water productivity; WP}

The recorded data of Water productivity (WP) were (30, 27.9, 36.1, 34.6, 37.1 and $34.1 \mathrm{~kg} / \mathrm{m}^{3}$ ) for treatments of FP100, FC100, DP75, DC75, DP50 and DC50 respectively as shown in Fig. (9). Total applied water were $\left(1192,1192,894,894,596\right.$, and $596 \mathrm{~m}^{3} /$ fed) for FP100, FC100, DP75, DC75, DP50 and DC50 treatments respectively. Pulse-deficit drip irrigation techniques 
were positively reflected on the increase of water productivity (WP). It was found that the highest water productivity was in the treatment of DP50 $\left(37.1 \mathrm{~kg} / \mathrm{m}^{3}\right)$ and that was better water saving strategy which conforms to (Silveira, et al., 2020). The lowest WP was in the treatment of FC100 $\left(27.9 \mathrm{~kg} / \mathrm{m}^{3}\right)$. Also, result of use deficit irrigation techniques only was the highest WP at DC75 $\left(34.6 \mathrm{~kg} / \mathrm{m}^{3}\right)$ which conforms to (Nangare, et al., 2016). The statistical analysis showed that, there were significant effects at the 0.01 probability level due to irrigation treatments on water productivity as shown in table (4).

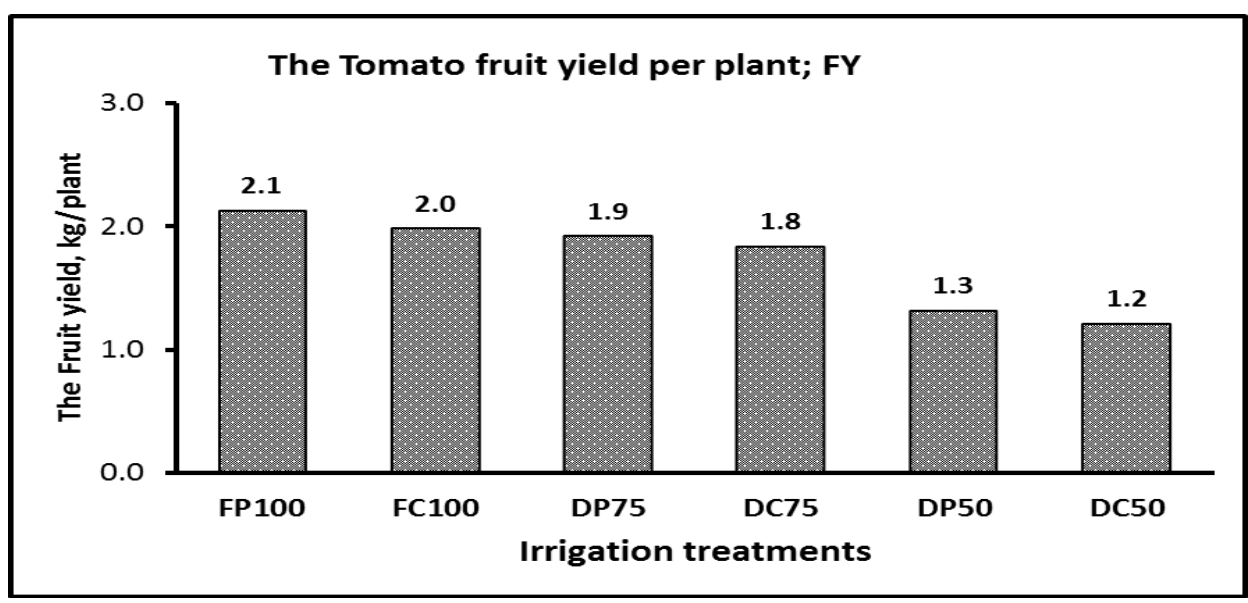

Fig. (7): The tomato yield per plant under different irrigation treatments.

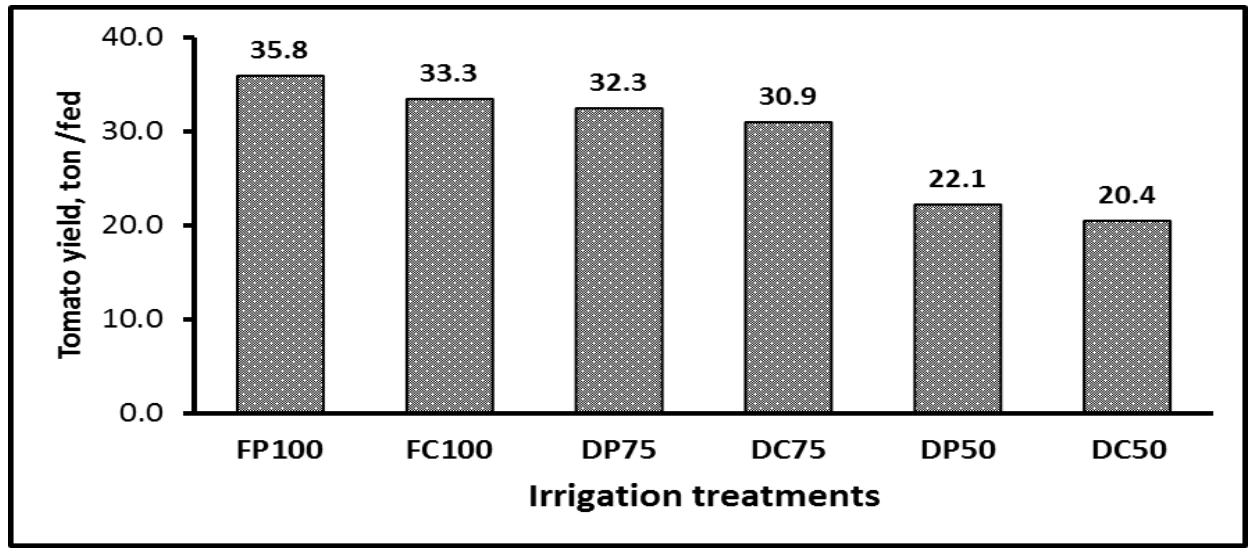

Fig. (8): The tomato yield per feddan under different irrigation treatments in greenhouse.

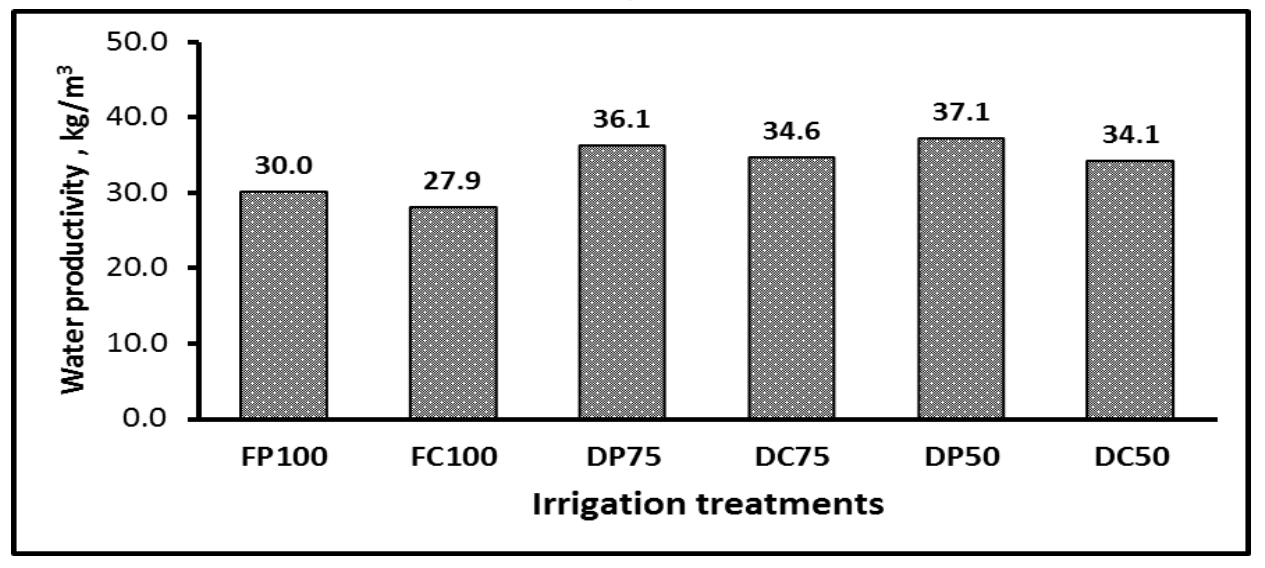

Fig. (9): Water productivity for irrigating tomato crop in greenhouse. 
Table (4): Statistical analysis of some growth and productivity parameters of Tomato under different treatments.

\begin{tabular}{|c|c|c|c|c|c|}
\hline Treatments & $\begin{array}{c}\mathrm{TY} \\
\text { (ton/fed) }\end{array}$ & $\begin{array}{l}\text { WP } \\
\left(\mathrm{kg} / \mathrm{m}^{3}\right)\end{array}$ & $\begin{array}{c}\text { FN } \\
\text { (fruits/ } \\
\text { plant) }\end{array}$ & $\begin{array}{c}\text { FW } \\
\text { (g/fruit) }\end{array}$ & $\begin{array}{c}\text { FY } \\
\text { (kg/plant) }\end{array}$ \\
\hline FP100 & $35.772 \mathrm{a}$ & $30.007 b c$ & $30.5 \mathrm{a}$ & $69.678 \mathrm{a}$ & $2.1293 \mathrm{a}$ \\
\hline FC100 & $33.299 \mathrm{a}$ & $27.932 \mathrm{c}$ & $29.6 \mathrm{a}$ & $66.932 \mathrm{a}$ & $1.9821 \mathrm{a}$ \\
\hline DP75 & $32.302 \mathrm{a}$ & $36.128 \mathrm{ab}$ & $28.8 \mathrm{ab}$ & $66.911 \mathrm{a}$ & $1.9227 \mathrm{a}$ \\
\hline DC75 & $30.899 \mathrm{a}$ & $34.559 \mathrm{ab}$ & $28.5 \mathrm{ab}$ & $64.448 \mathrm{a}$ & $1.8392 \mathrm{a}$ \\
\hline DP50 & $22.127 \mathrm{~b}$ & $37.122 \mathrm{a}$ & $25.0 \mathrm{~b}$ & $54.036 \mathrm{~b}$ & $1.3171 \mathrm{~b}$ \\
\hline DC50 & $20.354 \mathrm{~b}$ & $34.147 \mathrm{abc}$ & $25.0 \mathrm{ab}$ & $45.602 \mathrm{c}$ & $1.2115 \mathrm{~b}$ \\
\hline P-value & 0.000 & 0.001 & 0.005 & 0.000 & 000 \\
\hline $\begin{array}{r}\text { Significance } \\
\text { level }\end{array}$ & $* *$ & $* *$ & $* *$ & $* *$ & $* *$ \\
\hline
\end{tabular}

*: Significance at the 0.05 probability level, and **: significance at the 0.01 probability level.

\section{Solar Irrigation parameters}

\section{a. Solar energy consumption; SEC}

Results showed saving in the solar energy consumption for irrigating tomato crop during growth season at applying the pulse-deficit and deficit drip irrigation techniques at levels of $75 \%$, and $50 \%$ ETc compared with full continuous and pulsed irrigation techniques at level of $100 \%$ ETc. The calculated data of SEC based on water requirements for Tomato crop during growth season were $(48.7,48.7,36.6,36.6,24.4$ and $24.4 \mathrm{kWh} /$ season) for treatments of FP100, FC100, DP75, DC75, DP50 and DC50 respectively as shown in Fig. (10). Operating times were (48, 48, 36, 36, 24, and 24 minutes) for FP100, FC100, DP75, DC75, DP50 and DC50 treatments respectively.

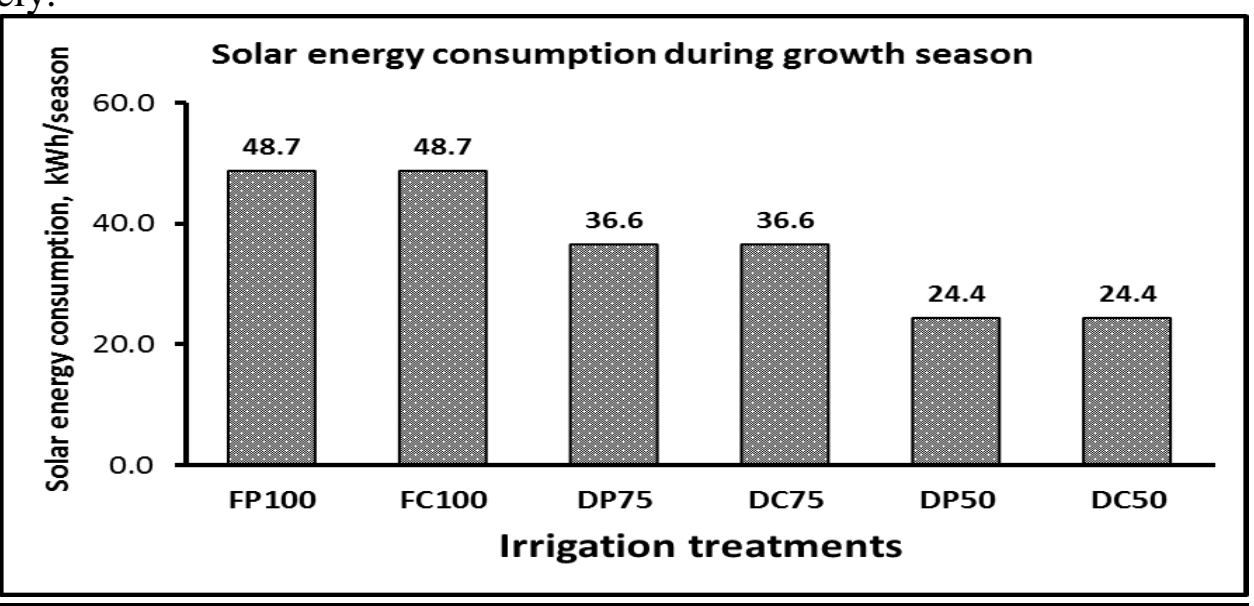

Fig. (10): Solar energy consumption for irrigating tomato crop in greenhouse.

\section{b. Solar energy productivity; SEP}

Solar energy productivity (SEP) is an effective indicator for maximizing the use of the solar energy for irrigating tomato crop in greenhouse during growth season. The recorded data of SEP were $(734,683,884,845,908$ and $835 \mathrm{~kg} / \mathrm{kWh})$ for treatments of FP100, FC100, DP75, DC75, DP50 and DC50 respectively as shown in Fig. (11). Results showed that the use of pulse- 
deficit drip irrigation techniques was positively reflected on the increase of solar energy productivity (SEP). It is found that the highest SEP was in the treatment of DP50 (908 kg/kWh) but, the lowest SEP were in the treatment of FC100 $(683 \mathrm{~kg} / \mathrm{kWh})$. Also, result of use deficit irrigation techniques was the highest SEP only at DC75 (845 kg/kWh).

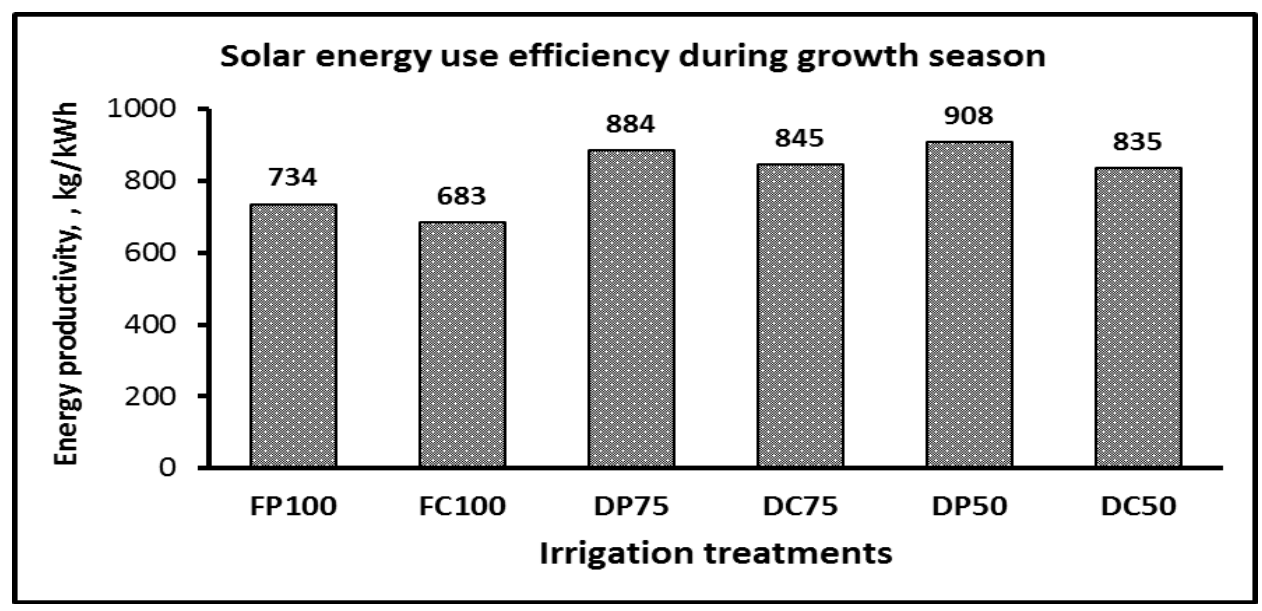

Fig. (11): Solar energy productivity for tomato crop product in greenhouse.

\section{CONCLUSION}

Field experiments were conducted to study the effect of using two effective irrigation techniques together such as the pulse-deficit irrigation powered by solar energy in greenhouse to investigate their impact on the Tomato productivity in buckets, water productivity and solar energy productivity. It was found that, the moisture content for tomato growth media after irrigation in Buckets increased largely under Pulsed-Deficit drip irrigation techniques compared to deficit irrigation techniques only. It can be noted that, there were no significant difference in both of the average number of tomato fruits and the average weight of tomato fruits per plant as a result of applying pulse-deficit drip irrigation techniques at levels of 100 and $75 \%$ irrigation water requirements compared with the continuous-deficit techniques. But there was reduction at level of 50\% irrigation water requirements. The highest tomato yield in the pulse-deficit drip irrigation was more than continuous-deficit irrigation techniques by $(7,4$, and $8 \%)$ for levels of $(100,75$, and $50 \%)$ respectively. The highest total tomato yield per feddan was achieved under the treatment of (FP100) was 35.8 ton/fed but, the lowest yield per plant in the treatment of DC50 was 20.4 ton/fed. The highest water productivity (WP) was $37.1 \mathrm{~kg} / \mathrm{m}^{3}$ when applying of (DP50). On the other hand the treatment of (FC100) gave the lowest WP of $27.9 \mathrm{~kg} / \mathrm{m}^{3}$. The WP in treatment of (DP50) increased by $33 \%$ while, total tomato yield per feddan decreased by $34 \%$ where it exposed to water stress $50 \%$ of irrigation water requirements compared with continuous-full irrigation (FC100) a control. Application of pulse-deficit irrigation (DP50) saved $50 \%$ of solar energy consumption and increase EUE (908 kg/kWh) by $33 \%$ as compared with (FC100). The statistical analysis was highly significant for the irrigation treatments on tomato productivity, (WP), and plant morphological characteristics. Irrigation with using pulsedeficit drip irrigation technique would enable a decrease in tomato yield because of using deficit irrigation technique, which exposed to water stress but increase in WP in all treatments. Therefore, we recommend using pulse-deficit irrigation (DP75) technique (water stress $25 \%$ of the needed irrigation water requirements) because it reduce tomato yield by $3 \%$ and increase water and energy productivity by 29.3 and $29.4 \%$ respectively. 


\section{REFERENCES}

Abd-elhakim, A. I. (2019). Soil conditioner effect on soil wetting patterns under pulsed drip irrigation system. Misr J. Ag. Eng., 36 (2): 473 - 492.

Abdel tawab, E. (2015). Effect of Pulse and Continuous Drip Irrigation on Soil Wetting Pattern. Thesis of M.Sc., Alex. Univ., Egypt.

Al-Ghobari, H. M., \& Dewidar, A. Z. (2018). Integrating deficit irrigation into surface and subsurface drip irrigation as a strategy to save water in arid regions. Agricultural Water Management, 209, 55-61.

Bakeer, G. A. A., El-Ebabi, F. G., El-Saidi, M. T., and Abdelghany, A. (2009). Effect of pulse drip irrigation on yield and water use efficiency of potato crop under organic agriculture in sandy soils. Misr J. Agric. Eng, 26, 736-765.

Chen, J.L., Kang, S.Z., Du, T.S., Qiu, R.J., Guo, P., Chen, R.Q., (2013). Quantitative response of greenhouse tomato yield and quality to water deficit at different growth stages. Agric. Water Manage. 129, 152-162. https://doi.org/10.1016/j.agwat.2013.07.011.

Devabhaktuni, V., Alam, M., Depuru, S. S. S. R., Green II, R. C., Nims, D., \& Near, C. (2013). Solar energy: Trends and enabling technologies. Renewable and Sustainable Energy Reviews, 19, 555-564.

Dijkstra, F.A., Carrillo, Y., Aspinwall, M.J., Maier, C., Canarini, A., Tahaei, H., Choat, B., Tissue, D.T., (2016). Water, nitrogen and phosphorus use efficiencies of four tree species in response to variable water and nutrient supply. Plant Soil 406, 187-199. https://doi.org/10.1007/s11104-016-2873-6.

English, M.J., (1990). Deficit irrigation. I. Analytical framework. J. Am. Soc. Civil Eng. 116 (IR3), 399-412.

English, M., Raja, S.N., (1996). Perspectives on deficit irrigation. Agric. Water Manage. 32, 114.

Eric, S., David, S. and Robert H. (2004). To pulse or not to pulse drip irrigation that is the question UF/IFAS - HORTICULTURAL SCIENCES DEPARTMENT. Florida,USA NFREC-SV-Vegetarian (04-05).

Hooshmand, M., Albaji, M., \& zadeh Ansari, N. A. (2019). The effect of deficit irrigation on yield and yield components of greenhouse tomato (Solanum lycopersicum) in hydroponic culture in Ahvaz region, Iran. Scientia Horticulturae, 254, 84-90.

Ismail, S. M., 2002. Design and management of field irrigation systems. Alex., Egypt.

Ismail, S. M., EL-Abdeen, T. Z., Omara, A. A., and Abdel-Tawab, E. (2014). Modeling the soil wetting pattern under pulse and continuous drip irrigation. American-Eurasian Journal Agricultural \& Environment Science, 14(9), 913-922.

James, L. G., (1988). Principles of farm irrigation systems design. John Wiley and Sons Limited.

Khalil, M. A. I. (1998). Water relations and irrigation systems. Knowledge facility. Alex., Egypt.

Karam, F., Lahoud, R., Masaad, R., Kabalan, R., Breidi, J., Chalita, C., \& Rouphael, Y. (2007). Evapotranspiration, seed yield and water use efficiency of drip irrigated sunflower under full and deficit irrigation conditions. Agricultural water management, 90(3), 213-223.

Kelley, L. C., Gilbertson, E., Sheikh, A., Eppinger, S. D., \& Dubowsky, S. (2010). On the feasibility of solar-powered irrigation. Renewable and Sustainable Energy Reviews, 14(9), 2669-2682. 
Khapte, P. S., Kumar, P., Burman, U., \& Kumar, P. (2019). Deficit irrigation in tomato: Agronomical and physio-biochemical implications. Scientia horticulturae, 248, 256-264.

Kirda, C., Moutonnet, P., Hera, C., Nielsen, D.R., (1999). Crop Yield Response to Deficit Irrigation. Kluwer Academic Publishers, Dordrecht.

Kirnak, H., Tas, I., Kaya, C., \& Higgs, D. (2002). Effects of deficit irrigation on growth, yield and fruit quality of eggplant under semi-arid conditions. Australian journal of agricultural research, 53(12), 1367-1373.

Kumar, M., Reddy, K. S., Adake, R. V., \& Rao, C. V. K. N. (2015). Solar powered microirrigation system for small holders of dryland agriculture in India. Agricultural Water Management, 158, 112-119.

Li, J., Zhang, J., and Rao, M. (2004). Wetting patterns and nitrogen distributions as affected by fertigation strategies from a surface point source. Agricultural Water Management, 67(2), 89-104.

Nangare, D. D., Singh, Y., Kumar, P. S., \& Minhas, P. S. (2016). Growth, fruit yield and quality of tomato (Lycopersicon esculentum Mill.) as affected by deficit irrigation regulated on phenological basis. Agricultural Water Management, 171, 73-79.

Qiu, R.J., Du, T.S., Kang, S.Z., Chen, R.Q., Wu, L.S., (2015). Influence of water and nitrogen stress on stem sap flow of tomato grown in a solar greenhouse. J. Am. Soc. Hortic. Sci. 140, 111-119.

Salokhe, V. M., Babel, M. S., \& Tantau, H. J. (2005). Water requirement of drip irrigated tomatoes grown in greenhouse in tropical environment. Agricultural Water Management, 71(3), 225-242.

Savić, S., Stikić, R., Radović, B. V., Bogičević, B., Jovanović, Z., \& Šukalović, V. H. T. (2008). Comparative effects of regulated deficit irrigation (RDI) and partial root-zone drying (PRD) on growth and cell wall peroxidase activity in tomato fruits. Scientia Horticulturae, 117(1), 15-20.

Silveira, L. K., Pavão, G. C., dos Santos Dias, C. T., Quaggio, J. A., \& de Matos Pires, R. C. (2020). Deficit irrigation effect on fruit yield, quality and water use efficiency: A longterm study on Pêra-IAC sweet orange. Agricultural Water Management, 231, 106019.

Skaggs, T. H., Trout, T. J., and Rothfuss, Y. (2010). Drip irrigation water distribution patterns: effects of emitter rate, pulsing, and antecedent water. Soil Science Society of America Journal, 74(6), 1886-1896.

Tognetti, R., d'Andria, R., Morelli, G., Calandrelli, D., Fragnito, F., (2004). Irrigation effects on daily and seasonal variations of trunk sap flow and leaf water relations in olive trees. Plant Soil 263, 249-264. https://doi.org/10.1023/B:PLSO.0000047738. 96931.91.

Yu, L., Zhao, X., Gao, X., \& Siddique, K. H. (2020). Improving/maintaining water-use efficiency and yield of wheat by deficit irrigation: A global meta-analysis. Agricultural Water Management, 228, 105906.

Wazed, S. M., Hughes, B. R., O’Connor, D., \& Calautit, J. K. (2017). Solar driven irrigation systems for remote rural farms. Energy Procedia, 142, 184-191.

Wazed, S. M., Hughes, B. R., O’Connor, D., \& Calautit, J. K. (2018). A review of sustainable solar irrigation systems for Sub-Saharan Africa. Renewable and Sustainable Energy Reviews, 81, 1206-1225.

Zaki, H. Z.; A. M. Altony and A. M.Taha (2010). Cultivation of tomatoes and beans under low plastic tunnels. Technical Bulletin No. 5, Agriculture Research Center, Ministry Of Agriculture. Egypt. 


\section{تأثير استخذام الري بالتنقيط الناقص النبضي على محصول الطماطم فى الصوب الزراعية تعمل بالطاقةة الثمسية}

د. أحمد إبراهيم عبد الحكيم'، د. محمد ابراهيم المعداوى ب، د. اسلام محمد السيد السباعي و د. دحسن ابراهيم عجيله؟r ' باحث ـ قسم بحوث هندسة الري و الصرف الحقلي ـ معهد بحوث الهندسة الزر اعية ـ مركز البحوث الزراعية ـ الدقي ـ الجيزة ـ مصر.

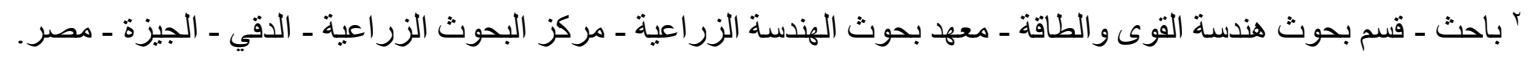
r باحث أول ـ قسم بحوث الهندسة الحيوية ـ معهد بحوث الهندسة الزراعية ـ مركز البحوث الزر اعية ـ الدقي ـ الجيزة ـ مصر.

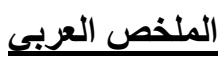

العمل المقدم اقترح در اسة تأثير استخدام طريقتين فعالتين للري معًا مثل الري بالتنقيط

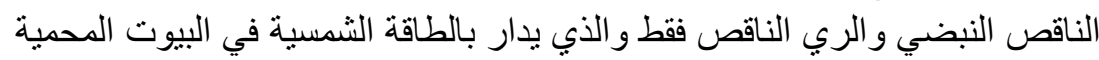

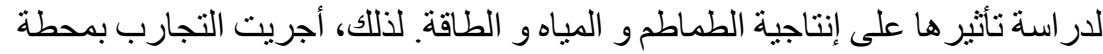

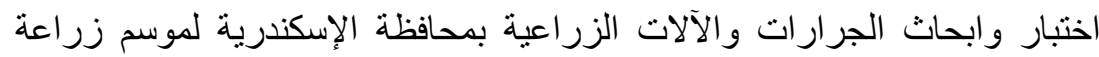

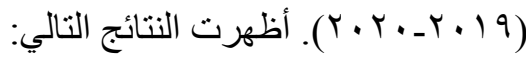

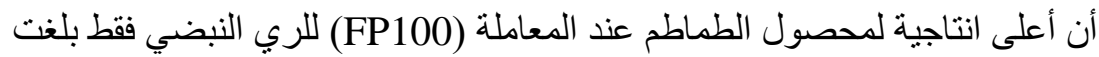

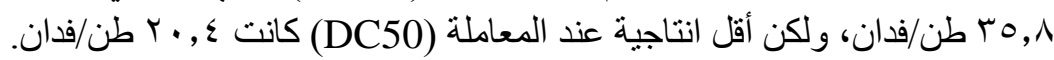

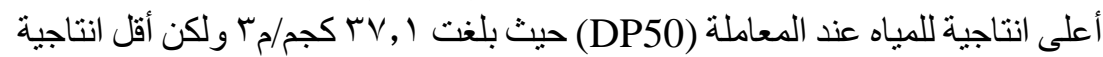

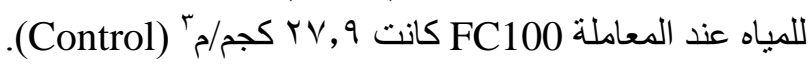

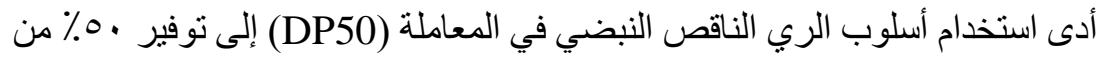
متطلبات استهلاك مياه الري و الطاقة الثمسية وتقليل إنتاجية محصول النقائل الطماطم للفدان

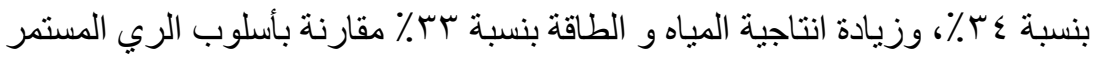
الكامل (FC100) كمعاملة مرجعية. اظهر التحليل الإحصائي تأثير معنوي معائي عالي لمعاملات الري على انتاجية محصول

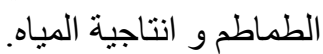

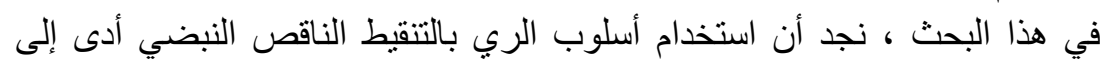

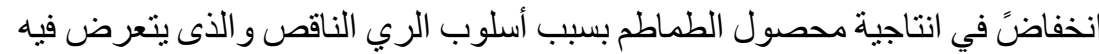

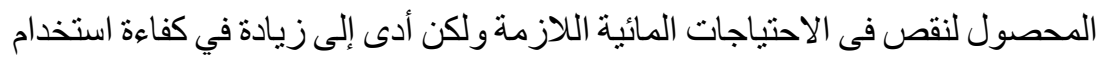

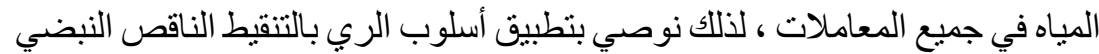

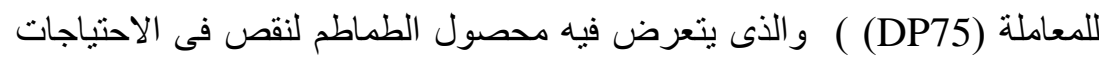

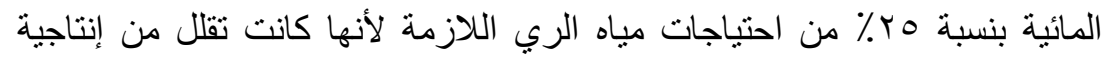

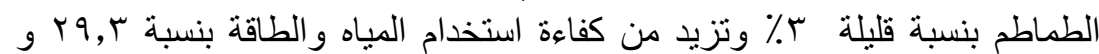

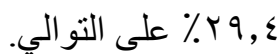

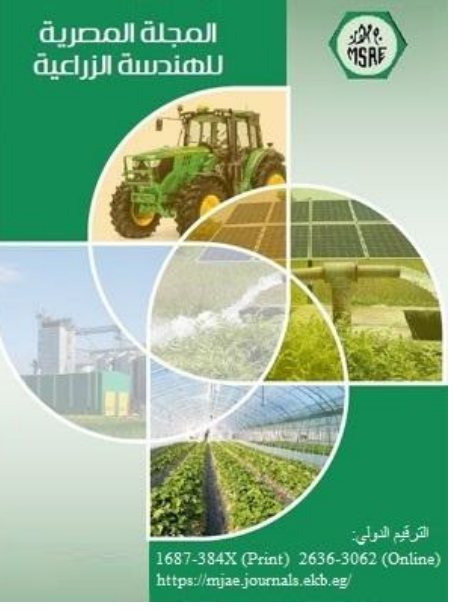

(C) المجلة المصرية للهندسة الزراعية

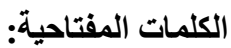

الري بالتتقيط الناقص النبضي، الطبة الطبة

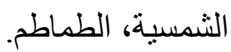

